RESEARCH Note

\title{
A review of recent sightings and reports of the giant tiger shrimp Penaeus monodon (Decapoda: Penaeidae) on the Mexican coast of the Gulf of Mexico (2012-2019)
}

Revisión de avistamientos y reportes recientes de camarón tigre gigante Penaeus monodon (Decapoda: Penaeidae) en la costa mexicana del Golfo de México (2012-2019)

\section{Armando T. Wakida-Kusunoki ${ }^{\circledR 1 *}$, José Luís Cruz-Sánchez ${ }^{\mathbb{1} 1}$ and Norma Angélica López-Téllez ${ }^{\left(D_{2}\right.}$}

${ }^{1}$ Centro Regional de Investigación Pesquera de Yucalpetén, Instituto Nacional de Pesca y Acuacultura, Boulevard del Pescador s/n esquina Antigua Carretera a Chelem 97320, Yucalpetén, Yucatán, México

${ }^{2}$ Centro Regional de Investigación Pesquera de Lerma, Instituto Nacional de Pesca y Acuacultura, Kilómetro 5 Carretera Campeche - Lerma \# 200, 24500 Campeche, Campeche, México

*Corresponding author: armandowakida@yahoo.com.mx

Abstract.- This work shows an update of the sightings and reports of tiger shrimp Penaeus monodon on the Mexican coast of the Gulf of Mexico recorded from 2012 to 2019 and reports the smallest specimen found in the western Atlantic. The results show an increase of almost $300 \%$ in sightings and reports since the first report. The zone with most sightings and reports was the coast of Campeche and Yucatán. The wide range of size and distribution of the captured specimens, including the smallest specimen found in the western Atlantic and the presence of females at an advanced stage of gonadal maturity, indicates that $P$. monodon has established itself in the area. The possible negative effects of such establishment make necessary the proposal of measures based on scientific evidence.

Key words: Crustacean, invasive species, Peninsula of Yucatán

\section{INTRODUCTION}

The Asian tiger shrimp, Penaeus monodon Fabricius, 1798 , is a penaeid widely distributed throughout most of the Indo-West Pacific region, however, its fishing grounds are mostly located in tropical countries, particularly in Indonesia, Malaysia and the Philippines (Motoh 1981) and it is an invasive species in the Eastern Mediterranean (Khafage et al. 2019) and West Africa (Clotilde-Ba et al. 1997). In the western Atlantic, it has been detected since the end of the 1980s, when Fausto-Filho (1987) first recorded the species in the littoral zone of Maranhão, Brazil. Later it was registered in 1988 in the Carolinas, Georgia, and Florida, USA (Fuller et al. 2014), Venezuela (Altuve et al. 2008), Colombia (Gómez-Lemos \& Hernando-Campos 2008), Puerto Rico (Knott et al. 2021), Cuba (Giménez et al. 2014), Costa Rica (Alfaro-Montoya et al. 2015) and Guatemala (Avalos 2015). The first report of this species in the Gulf of Mexico was in 2006 (Knott et al. 2021) when one male was captured in Mississippi, USA.
On the Mexican coast of the Gulf of Mexico, first reports were made in the northwest (Tamaulipas) and southeast (Campeche and Tabasco) areas (Wakida-Kusunoki et al. 2013); and it has since been reported in other places, such as Veracruz (Morán-Silva et al. 2014) and the Yucatán Peninsula (Wakida-Kusunoki et al. 2016a, b).

Fuller et al. (2014) suggest that the most likely introduction routes into the southeastern US were escapement from aquaculture facilities following flooding by storms and hurricanes, or through migration from areas where tiger shrimp have previously established in the wild. The route of introduction of $P$. monodon on the Mexican coasts may be the result of migration of post larvae and juveniles from areas where this species was already established, probably from the northern Gulf of Mexico or the Caribbean area. 
Some authors describe an exotic species as being established when a population perpetuates itself without the need for new introductions and successful breeding exists (Williamson 1996, Colautti \& MacIsaac 2004).

This work provides updated information on reported sightings of $P$. monodon on the Mexican coast of the Gulf of Mexico and reports the smallest specimen found in the western Atlantic.

\section{MATERIALS AND METHODS}

Collected data of $P$. monodon sightings and reports on the Mexican Coast of the Gulf of Mexico were compiled by two procedures; the first was an Internet survey where scientific papers, newspapers, biodiversity database (iNaturalista $2021^{1}$, Global Biodiversity Information Facility, GBIF²) and Scientific Collections (Portal de Datos Abiertos UNAM ${ }^{3}$, $\mathrm{BDMY}^{4}$ ) were revised. The information from newspapers was used only when it presented photos where the species could be clearly identified. The second procedure was by consulting the reported data from the invasive species campaign by the National Aquaculture and Fisheries Institute (INAPESCA, Mexico). This campaign consisted of gathering data and invasive specimens through a series of posters and social networking events to report and deliver captured specimens, such as tiger shrimp and the lionfish Pterois volitans (Linnaeus, 1758).

Each donor who delivered a specimen and gave information about the catch (the catch area and fishing gear used, geographic position and depth) received a reward. The total length (TL) of donated specimens was measured from the base of the rostrum to the end of the telson using a ictiometer $( \pm 0.1 \mathrm{~cm})$ and the carapace length (CL) with a caliper $( \pm 0.1 \mathrm{~mm})$. Total weight $(\mathrm{TW})$ was determined using a scale ( $0.1 \mathrm{~g}$ accuracy).
The size distribution by sex of the donated shrimp was determined; the shrimp were also divided by the mean size at first maturity by sex estimated by Motoh (1985) to differentiate recruits from reproductive adults.

\section{RESULTS AND DISCUSSION}

A total of 63 specimens were collected or reported between 2012 and 2019 with the largest number of reports made in 2019. The states with the most reports are Yucatán and Campeche (Table 1).

Most of the reports were from the INAPESCA's invasive species reporting campaign (67\%) and scientific publications (27\%). Biodiversity database and newspaper reports accounted for $3 \%$ each. The information found in the scientific collection corresponded to specimens deposited and cited by the scientific publications.

Table 1. Number of tiger shrimp Penaeus monodon obtained from sightings and reports by Mexican states in the Gulf of Mexico (20122019) from the invasive species detection campaign by the National Aquaculture and Fisheries Institute (INAPESCA, Mexico) and other sources [Wakida-Kusunoki et al. (2013), Moran-Silva et al. (2014), Wakida-Kusunoki et al. (2016a, b), Gómez-Ponce et al. (2020), GaxiolaCortés (2020) ${ }^{5}$; Data base: iNaturalista ${ }^{1}$ and GBIF ${ }^{2}$; Newspaper: Diario de Xalapa ${ }^{6}$, Milenio ${ }^{7}$ / Número de camarones tigres Penaeus monodon obtenidos de avistamientos y reportes de los estados mexicanos en el Golfo de México (2012-2019) por la campaña de detección de especies invasoras del Instituto Nacional de Pesca y Acuacultura y otras fuentes

\begin{tabular}{ccccccc}
\hline \multirow{2}{*}{ Year } & \multicolumn{6}{c}{ States } \\
\cline { 2 - 7 } & Tamaulipas & Veracruz & Tabasco & Campeche & Yucatán & Total \\
\hline 2012 & 3 & - & 1 & 5 & - & 9 \\
2013 & - & - & - & 1 & - & 1 \\
2014 & 1 & 2 & - & - & 3 & 6 \\
2015 & - & 2 & - & 1 & 2 & 5 \\
2016 & - & 1 & - & - & - & 1 \\
2017 & - & 3 & - & - & 1 & 4 \\
2018 & 2 & 1 & - & 5 & 3 & 11 \\
2019 & 4 & 3 & 4 & 5 & 10 & 26 \\
Total & 10 & 12 & 5 & 17 & 19 & 63 \\
\hline
\end{tabular}
${ }^{1}$ iNaturalista. 2021. Observaciones Penaeus monodon. Red iNaturalist, California Academy of Sciences y National Geographic Society. <https://www.
naturalista.mx/observations?place_id=6793\&taxon_id=209120>

${ }^{2}$ Global Biodiversity Information Facility. GBIF -Infraestructura Mundial de Información en Biodiversidad, Copenhagen. <https://www.gbif.org/es/ occurrence/search?q=Penaeus\%20monodon\&country=MX>

${ }^{3}$ Dirección General de Repositorios Universitarios, Universidad Nacional Autónoma de México. Portal de Datos Abiertos UNAM, Colecciones Universitarias, Colecciones Universitarias, Colecciones Biológicas. Universidad Nacional Autónoma de México, México. <https://datosabiertos.unam. $\mathrm{mx} /$ biodiversidad/>

${ }^{4}$ Crustáceos de la Península de Yucatán, Biodiversidad Marina de Yucatán - Base de datos, BioDiversidad Marina de Yucatán (BDMY), Facultad de Ciencias de la UNAM, México <https://www.bdmy.org.mx/datasetsbdmy>

${ }^{5}$ Gaxiola-Cortés MG. 2020. La llegada del camarón tigre a México: efecto de las actividades antropogénicas en la biodiversidad de camarones peneidos del Atlántico Americano, número III. <https://scme.mx/la-llegada-del-camaron-tigre-a-mexico-efecto-de-las-actividades-antropogencias-en-labiodiversidad-de-camarones-peneidos-del-atlantico-americano>

${ }^{6}$ Periódico Diario de Xalapa, 26 de abril 2019. <https://www.diariodexalapa.com.mx/local/capturan-camaron-tigre-de-33-cm-especie-en-peligro-deextincion-en-tecolutla-3370918.html>

${ }^{7}$ Periódico Milenio <https://www.milenio.com/estados/pescan-camaron-20-cm-laguna-tamiahua> 
The spatial distribution of the tiger shrimp reported in this study (Fig. 1) matches the potential prediction models in the Mexican Gulf based on environmental variables and reports (Petatán-Ramírez et al. 2020), except that the Yucatán and Campeche areas have the highest number of recorded sightings. This may be a result of the limited sighting information used in the models or the fact that the effort to detect tiger shrimp has been greater in this area than others.

Another aspect in the distribution and number of tiger shrimp reports could be their diel behavior. The tiger shrimp is nocturnal (Motoh 1981, Primavera \& Lebata 1995), therefore its catchability is higher at night.

In the lagoons and littoral zones of Campeche, Tabasco and Veracruz, the target species of the shrimp fisheries are white shrimp Penaeus setiferus and the seabob shrimp Xiphopenaeus kroyeri, which are captured during daylight hours (Wakida-Kusunoki et al. 2006); this could explain the few reports and sightings of tiger shrimp in this area. On the other hand, in Yucatán, shrimp fishing takes place during night hours since the target species is the pink shrimp
Penaeus duorarum Burkenroad, 1939 and P. brasiliensis Latreille, 1817 (Wakida-Kusunoki et al. 2016c), which could be the cause of the larger number of reports in this area.

The size distribution ranged between 43 and $345 \mathrm{~mm}$ TL, where $67 \%$ were female and $33 \%$ male (Fig. 2). The spatial distribution of the lengths matches that reported by Motoh (1985), small sizes ( $<168 \mathrm{~mm}$ TL) being found in the lagoon and inner and outer littoral zones and the large sizes in the outer littoral zone (> $168 \mathrm{~mm} \mathrm{TL})$.

Among the organisms reported, a juvenile tiger shrimp collected on 23 December 2019 in Celestun Lagoon in the Yucatán Peninsula was the smallest reported for the Atlantic American coast (Zink et al. 2018, Aguirre-Guzmán \& López-Acevedo 2020). This specimen weighed $4 \mathrm{~g}$ and measured $43 \mathrm{~mm}$ TL and $10.5 \mathrm{~mm} \mathrm{CL}$, a difference of 4 $\mathrm{mm}$ TL and $2 \mathrm{~mm}$ CL smaller than the previous smallest specimen captured in Southern Biscayne Bay and reported by Zink et al. (2018).
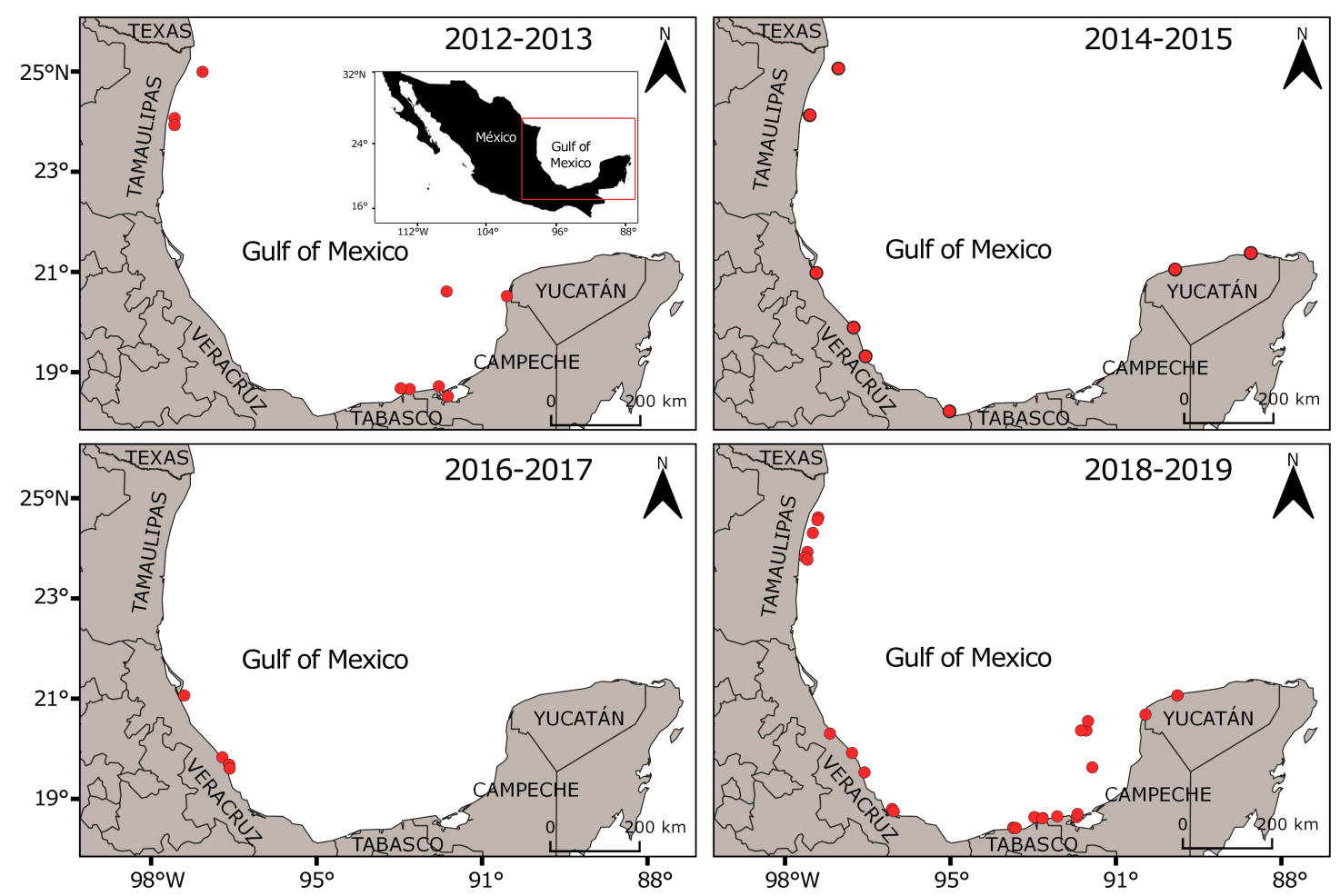

Figure 1. Distribution of the reports of giant tiger shrimp Penaeus monodon in the Mexican Gulf of Mexico every two years (2012-2019) / Distribución de los reportes de camarón tigre gigante Penaeus monodon en las costas mexicanas del Golfo de México de forma bianual (2012-2019) 


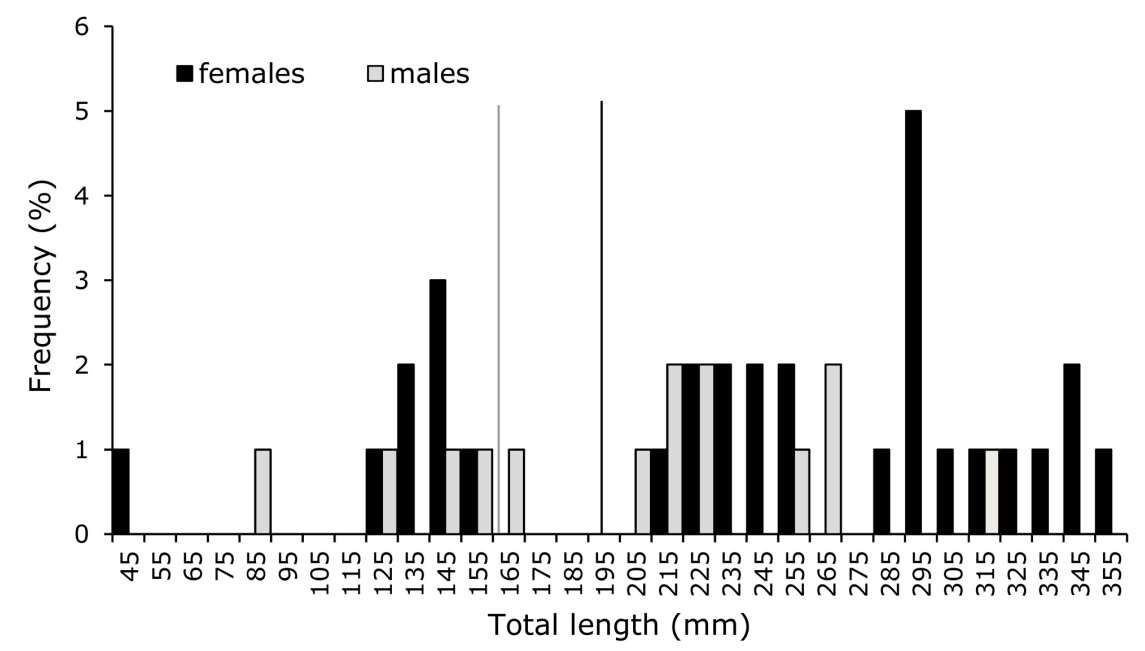

Figure 2. Size distribution of the reported specimens of giant tiger shrimp Penaeus monodon. The vertical lines represent the minimum gonadic maturity size by sex reported by Motoh (1985) (gray line= male, black line= female) / Distribución de tallas de los organismos reportados de camarón tigre gigante Penaeus monodon. Las líneas verticales representan el tamaño mínimo de madurez gonádica por sexo reportada por Motoh (1985) (línea gris= macho, línea negra= hembra)

The identification of this small specimen was based on its dark coloration, rostrum with six dorsal and three ventral spines (Motoh 1985), lack of prominent adrostral sulci of the carapace and dorsolateral sulci of the 6th abdominal segment. These last morphological characteristics are the main means to differentiate tiger shrimp from the common species of penaeid shrimp in the area ( $P$. duorarum and $P$. brasiliensis) (Zink et al. 2018).

The specimen was deposited in the Crustacean Collection of Yucatán, UNAM-Sisal (catalog number YUC-CC-255-11-006771).

The presence of the smallest specimen in the western Atlantic and a breeding female on the coast of Campeche (Gómez-Ponce et al. 2020), as well as reports of juveniles and mature females throughout the Mexican coast of the Gulf of Mexico, suggests that there are already reproductive populations in this region (Fuller et al. 2014).

Petatán-Ramírez et al. (2020), using a potential distribution model of $P$. monodon based on environmental information of native and invaded distribution zones, mentioned that the countries where tiger shrimp could become established are Mexico and Cuba.
The information on number and geographical distribution from the reports and sightings indicates that tiger shrimp populations are established at stage IVa. This stage of establishment of an invasive species is defined when the reports of presence are widespread but rare (Colautti \& MacIsaac 2004).

The ecological effects of the establishment of this species in the Mexican area of the Gulf of Mexico have not been estimated, but it is known than juveniles of $P$. monodon are effective zooplankton predators (Chen \& Chen 1992) and that adults are more aggressive predators of soft-bodied invertebrate benthic organisms than other native shrimp species (Marte 1980, Motoh 1981), and may be potential predators of native shrimp species (Knott et al. 2021). Moreover, the giant tiger shrimp is able to compete for food and space with other species, interfering with the breeding success of native shrimp species (WakidaKusunoki et al. 2016a). The pink shrimp P. duorarum is the main species captured in the area with the highest number of reports. Its stock is considered over-exploited (DOF 2012) ${ }^{8}$, a situation which could be aggravated by the presence of the invasive tiger shrimp.

${ }^{8}$ DOF. 2012. Acuerdo por el que se da a conocer la Actualización de la Carta Nacional Pesquera. Diario Oficial de la Federación, Ciudad de México, 24 de agosto del 2012. <https://www.gob.mx/inapesca/documentos/actualizacion-carta-nacional-pesquera-2012> 
Another possible effect could be the introduction of pathogens. Although no viruses have currently been detected in the captured organisms, the tiger shrimp is known to be the carrier of several important viral diseases such as white spot syndrome virus (WSSV) (De la Peña et al. 2007, Fuller et al. 2014, Sandoval et al. 2014).

The possible negative effects associated with the presence of tiger shrimp on the ecosystem and the importance of shrimp fisheries in the area highlight the need for control measures based on the scientific evidence.

\section{ACKNOWLEDGMENTS}

This work was part of the research project "Estimation of the periods of recruitment of shrimp in coasts of Yucatán and detection and monitoring of invasive species that could affect the shrimp population" funded by the National Institute of Fisheries and Aquaculture (INAPESCA). The authors thank the fishermen of the small-scale and industrial shrimp fisheries of Tamaulipas, Veracruz, Campeche and Yucatán for the specimen donations, Alejandro González Cruz, Karina Ramírez López, Rogelio Estrada García, Briseida Álvarez López, for their support in collecting specimens, Ramon Isaac Rojas Gonzalez and Esteban Bada for their valuable observations on the manuscript and anonymous reviewers for their valuable comments.

\section{LITERATURE CITED}

Aguirre-Guzman G \& EA Lopez-Acevedo. 2020. Presencia del camarón tigre gigante Penaeus monodon (Decapoda: Penaeidae) en las costas del Atlántico Americano. Revisión. Revista de Biología Marina y Oceanografía 55(2): 90-99.

Alfaro-Montoya J, AM Monge-Ortiz, D MartínezFernández \& E Herrera-Quesada. 2015. First record of the nonindigenous Penaeus monodon Fabricius, 1798 (Penaeidae) in the Caribbean Sea of Costa Rica, Central America, with observations on selected aspects of its reproductive biology. BioInvasions Records 4(5): 217-222.

Altuve DE, LA Marcano, JJ Alió \& JP Blanco-Rambla. 2008. Presencia del camarón tigre Penaeus monodon (Fabricius, 1798) en la costa del delta del río Orinoco y Golfo de Paria, Venezuela. Memoria de la Fundación La Salle de Ciencias Naturales 68(169): 83-92.

Avalos CG. 2015. Presencia y biometría del camarón tigre, Penaeus monodon (FABRICIUS, 1798), en la bahía de Amatique, Izabal. Tesis de Licenciatura, Centro de Estudios del Mar y Acuicultura, Universidad de San Carlos de Guatemala, Guatemala, 45 pp.

Chen YL \& HY Chen. 1992. Juvenile Penaeus monodon as effective zooplankton predators. Aquaculture 103(1): $35-44$.

Clotilde-Ba FL, I Niamadio, Y Diatta \& C Capapé. 1997. First records of the giant tiger prawn Penaeus monodon (Fabricius, 1798) (Crustacea: Penaeidae) in the marine waters of Senegal (eastern tropical Atlantic). Bocagiana 185: $1-7$.
Colautti RI \& HJ MacIsaac. 2004. A neutral terminology to define 'invasive' species. Diversity and Distributions 10: $135-141$.

De la Peña D, C Lavilla-Pitogo, C Villar, M Paner, C Sombito \& G Capulos. 2007. Prevalence of white spot syndrome virus (WSSV) in wild shrimp Penaeus monodon in the Philippines. Diseases of Aquatic Organisms 77: 175-179.

Fausto-Filho J. 1987. Registro da captura de Penaeus monodon Fabricius no litoral do estado do Maranhão, Brasil (Crustacea: Penaeidae). Arquivos de Ciências do Mar 26(1): 81-82.

Fuller PL, DM Knott, PR Kingsley-Smith, JA Morris, CA Buckel, ME Hunter \& LD Hartman. 2014. Invasion of Asian tiger shrimp, Penaeus monodon Fabricius, 1798, in the western north Atlantic and Gulf of Mexico. Aquatic Invasions 9(1): 59-70.

Giménez E, L Pérez, BJ Ceballos, D Cabrera, J Rodriguez \& R Almeida. 2014. The giant tiger prawn, Penaeus monodon, distribution (Fabricius, 1798) in the Cuban shelf. Perspectives and futures actions. Revista Cubana de Investigaciones Pesqueras 31(1): 30-35.

Gómez-Lemos LA \& N Hernando-Campos. 2008. Presencia de Penaeus monodon Fabricius (Crustacea: Decapoda: Penaeidae) en aguas de la Guajira Colombiana. Boletín de Investigaciones Marinas y Costeras, INVEMAR 37(2): 221-225.

Gómez-Ponce M, N Bolaños-Martínez, P Díaz-Jaimes, J Bortolini-Rosales \& P Castellanos-Pérez. 2020. A new record of a tiger shrimp Penaeus monodon Fabricius, 1798 breeding female in the coast of Campeche, Mexico. Latin American Journal of Aquatic Research 48(1): 150-155.

Khafage AR, SM Taha \& MA Attallah. 2019. Presence of tiger shrimp Penaeus monodon Fabricius, 1798 (Penaeidae) in the Egyptian commercial shrimp catch, Alexandria, Egypt. Egyptian Journal of Aquatic Research 45(2): 183187.

Knott DM, PL Fuller, AJ Benson \& ME Neilson. 2021. Penaeus monodon. Nonindigenous Aquatic Species Database. U.S. Geological Survey (USGS), Gainesville. <https://nas. er.usgs.gov/queries/factsheet.aspx?SpeciesID=1209>

Marte CL. 1980. The food and feeding habit of Penaeus monodon Fabricius collected from Makato River, Aklan, Philippines (Decapoda Natantia). Crustaceana 38: 225-236.

Morán-Silva A, ML Jiménez-Badillo, S Cházaro-Olvera, C Meiners-Mandujano, G Galindo-Cortes \& J OviedoPerez. 2014. First record of tiger shrimp (Penaeus monodon Fabricius, 1798), in the southcentral coast of Veracruz, Gulf of Mexico. BIOCYT Biología, Ciencia y Tecnología 7(28): 509-514.

Motoh H. 1981. Studies on the fisheries biology of the giant tiger prawn, Penaeus monodon in the Philippines. Technical Report 7: 1-128. Aquaculture Department, Southeast Asian Fisheries Development Center, Tigbauan.

Motoh H. 1985. Biology and ecology of Penaeus monodon. In: Taki Y, JH Primavera \& JA Llobrera (eds). Proceedings of the First International Conference on the Culture of Penaeid Prawns/Shrimps, pp. 27-36. Aquaculture Department, Southeast Asian Fisheries Development Center, Tigbauan. 
Petatán-Ramírez D, L Hernández, EE Becerril-García, P Berúmen-Solórzano, D Auliz-Ortiz \& H Reyes-Bonilla. 2020. Potential distribution of the tiger shrimp Penaeus monodon (Decapoda: Penaeidae), an invasive species in the Atlantic Ocean. Revista de Biología Tropical 68(1): 156-166.

Primavera JH \& J Lebata. 1995. Diel activity patterns in Metapenaeus and Penaeus juveniles. Hydrobiologia 295(1-3): 295-302.

Sandoval LA, J Leal-Florez, A Taborda \& JG Vásquez. 2014. Spatial distribution and abundance of the giant tiger prawn, Penaeus monodon (Fabricius, 1798), in the Gulf of Urabá (Caribbean), Colombia, South America. BioInvasion Record 3(3): 169-173.

Wakida-Kusunoki AT, R Solana-Sansores, ME SandovalQuintero, G Núñez-Márquez, JA Uribe-Martínez, A González-Cruz \& M Medellín-Ávila. 2006. Camarón del Golfo de México y mar Caribe. En: Arreguín-Sánchez F, L Beléndez-Moreno, I Méndez Gómez-Humaran, R SolanaSansores \& C Rangel-Dávalos (eds). Sustentabilidad y pesca responsable en México. Evaluación y manejo, pp. 425-476. Instituto Nacional de la Pesca, SAGARPA, Ciudad de México.

Wakida-Kusunoki AT, RI Rojas-González, A GonzálezCruz, LE Amador-del Ángel, JL Sánchez-Cruz \& NA López-Tellez. 2013. Presence of giant tiger shrimp Penaeus monodon Fabricius, 1798 on the Mexican coast of the Gulf of Mexico. Bioinvasion Records 2(4): 325-328.
Wakida-Kusunoki AT, D De Anda-Fuentes \& NA LópezTéllez. 2016a. Presence of giant tiger shrimp Penaeus monodon (Fabricius 1798) on Eastern Peninsula of Yucatan Coast, Mexico. Latin American Journal of Aquatic Research 44(1): 155-158.

Wakida-Kusunoki AT, AH Medina-Quijano \& I RojasGonzález. 2016b. Presence of tiger shrimp Penaeus monodon in the Chelem lagoon, Yucatan, Mexico. Ciencia Pesquera 24(2): 53-57.

Wakida-Kusunoki AT, RI Rojas-González, A Toro-Ramírez, HA Medina-Quijano, JL Cruz-Sánchez, LD SantanaMoreno \& I Carrillo-Nolasco. 2016c. Caracterización de la pesca de camarón en la zona costera de Campeche y Yucatán. Ciencias Pesqueras 24(1): 3-13.

Williamson M. 1996. Biological invasions, 244 pp. Chapman \& Hall, London.

Zink IC, TL Jackson \& JA Browder. 2018. A note on the occurrence of non-native tiger prawn (Penaeus monodon Fabricius, 1798) in Biscayne Bay, FL, USA and review of South Florida sighting and species identification. BioInvasions Record 7(3): 297-302. 